\title{
ANALISIS KETIMPANGAN PEMBANGUNAN ANTAR DAERAH SUMATERA UTARA BAGIAN TIMUR
}

\author{
Dewi junisa \\ Dea arum sekar arimbi \\ Efrianti situmorang \\ Evi erviani \\ Febriza handayani \\ Jesenia siagian \\ Jurusan Pendidikan Ekonomi, Fakultas Ekonomi \\ Universitas Negeri Medan \\ Email:junisadewi@gmail.com
}

\begin{abstract}
This research purposes to analyse the building imbalance in every regencies/cities in East, North Sumatra: 1. Asahan regency, 2.Batu Bara regency,3. Labuhan Batu regency, 4.south Labuhan Batu regency, 5.north Labuhan Batu regency, 6.Tanjung Balai city to classify in every those districts. In this research uses Williamson's Index approached method to quantify the building imbalance and tipology klassen's analysis to classify economics growth in every districts. This analysis uses Bruto Regional Domestic Product data per capita at the constant price in 2000 and for North Sumatra in 2010-2012. This research, explains that 1. according to williamson's index analysis the imbalance that happened in East-North Sumatra in 2011 decreasing between 1.7 being 1.47 and in 2012 increasing between 1.65 because it is far from the 0 ,so there is a high imbalance in East-North Sumatra. 2 according to tipology klassen's analysis, there is no an advance and arise district in East- North Sumatra but including Batu Bara as an oppressed district as an advance one, still now the advance district is Labuhan Batu District, South Labuhan Batu and North Labuhan Batu and also Asahan and Tanjung Balai as the left behind district.
\end{abstract}

Keywords: Williamson's Index, Tipology Klassen, Bruto Regional Domestic Product 


\section{PENDAHULUAN}

1 danya realitas kesenjangan regional, distribusi spasial, sumber daya alam menjadi dampak dari pembangunan daerah yang tidak merata. Pembangunan sarana dan prasarana umumnya lebih mengutamakan untuk daerah dengan kepadatan penduduk yang tinggi, sehingga dapat juga dikatakan bahwa ketimpangan antar daerah erat kaitannya dengan ketimpangan penyebaran penduduk (Restiatun, 2009:77).

Penyebaran penduduk antar daerah tentu berbeda-beda, hal itu terjadi karena ketersediaan lapangan pekerjaan, sumber daya alam serta faktor lain juga mengalami perbedaan. Penyebaran penduduk yang terlalu padat serta berlimpahnya kekayaan sumber daya alam membuat terjadinya pemekaran suatu daerah. Daerah yang mekar tersebut tentu akan menjadi pusat perhatian pembangunan fasilitas Publik. Tentu akan membuat terjadinya ketimpangan daerah yang baru saja mekar dan yang lain. Kesenjangan pembangunan mengakibatkan ketidakmerataan kemakmuran/ kesejahteraan serta kemajuan daerah tersebut.

Menurut Schumpeter pembangunan ekonomi bukan merupakan proses yang harmonis atau gradual, tetapi merupakan perubahan yang spontan dan tidak terputus-putus. Pembangunan ekonomi disebabkan oleh perubahan terutama dalam lapangan industry dan perdagangan. Pembangunan ekonomi berkaitan dengan pendapatan perkapita dan pendapatan nasional. pendapatan perkapita yaitu pendapatan rata-rata penduduk suatu daerah sedangkan pendapatan nasional merupakan nilai produksi barang-barang dan jasa-jasa yang diciptakan dalam suatu perekonomian didalam masa satu tahun. Pertambahan pendapatan nasional dan pendapatan perkapita dari masa ke masa dapat digunakan untuk mengetahui laju pertumbuhan ekonomi dan juga perkembangan tingkat kesejahteraan masyarakat suatu daerah.

Banyak daerah yang memiliki pendapatan perkapita serta laju pertumbuhan di suatu daerah mengalami peningkatan, namun hal itu belum tentu membuat pembangunan daerah tersebut juga mengalami peningkatan, hal ini diakibatkan oleh faktor-faktor yang sedikit banyaknya akan mempengaruhi pembangunan. Pada realistisnya ketimpangan daerah di Sumatera Utara sangat tinggi, dimana sering kita temui adanya 
perbedaan pembangunan daerah yang satu dengan yang lainnya, adanya gedung pencakar langit dan adapula rumah kardus. Hal ini adanya kesenjangan kesejahteraan yang didapatkan oleh sekelompok orang.

Sumatera Utara merupakan salah satu provinsi/daerah yang cukup kaya baik dengan hasil bumi berupa migas, hasil tambang dan hasil perkebunan berupa kelapa sawit, tebu, karet dan lainnya. Akan tetapi masyarakat masih belum puas dengan pembangunan yang dilakukan oleh pemerintah terhadap masing-masing daerah. Hal itu akan menimbulkan banyak gejolak bagi daerah yang tidak puas. Dari hasi studi Yeniwati (2013), didapatkan hasil bahwa pembangunan ekonomi Provinsi Sumatera Utara memiliki ketimpangan rata-rata keatas, pada tahun 2010 yaitu 0,483. Tentu hal tersebut hanya secara keseluruhan, belum secara rinci menghitung besar ketimpangan masing-masing bagian Sumatera Utara.

Dalam penelitian ini akan menghitung besar ketimpangan pembangunan daerah bagian timur. Dimana daerah bagian timur Sumatera Utara yang issunya akan mekar menjadi Sumatera Pantai Timur. Sumatera utara bagian timur merupakan bagian pesisir yang secara global memiliki kekayaan alam yang sama, namun tetap saja terjadinya kesenjangan pertumbuhan dan pembangunan ekonomi. Berdasarkan BPRB perkapita setiap bagian Kabupaten/Kota Sumatera Utara bagian timur yang terdiri dari 5 Kabupaten 1 kota, yaitu: 1). kabupaten Asahan, 2). Kabupaten Labuhan Batu, 3). Kabupaten Labuhan Batu Utara, 4). Kabupaten Labuhan Selatan, 5). Kabupaten Batu Bara, 6). Kota Tanjung Balai memiliki peningkatan setiap tahun nya.

Penelitian ini bertujuan untuk mengetahui seberapa besar ketimpangan pembangunan Sumatera Utara Bagian Timur masing-masing daerah, untuk mengetahui keadaan pertumbuhan ekonomi dan agar kita mengetahui faktor-faktor lain yang ekstrim yang mempengaruhi ketimpangngan pada daerah tersebut.

Semakin berkembangnya pembangunan mendorong pemerintah pusat dan daerah berupaya merencanakan semaksimal mungkin dengan mengharapkan tercapainya hasil yang optimal serta mempertimbangkan kondisi dan potensi yang dimiliki daerah. Dalam mengkaji masalah perencanaan dan pembangunan daerah, maka yang menjadi titik perhatian mendasar adalah mengenai konsep dasar daerah, berbagai studi empiris 
tentang kegiatan ekonomi ditinjau dari sudut penyebarannya di berbagai daerah.

Dari sudut ilmu ekonomi, pembangunan biasa diartikan sebagai upaya mencapai tingkat pertumbuhan pendapatan perkapita (income per capita) yang berkelanjutan agar negara dapat memperbanyak output yang lebih cepat dibandingkan dengan jumlah pertumbuhan penduduk. Ilmu ekonomi pembangunan merupakan pengembangan yang nyata dan juga penting terhadap ilmu ekonomi tradisional dan ilmu ekonomi politik. Selain menaruh perhatian terhadap sumber daya secara efisien dan pertumbuhan output secara berkelanjutan dari waktu ke waktu, ilmu ekonomi pembangunan juga berfokus pada mekanisme ekonomi, social, dan lembaga yang diperlukan untuk menghasilkan peningkatan standar hidup secara cepat dan berskala besar dari kaum miskin di Negara-negara berkembang (Todaro, 2011: 31).

Diterbitkannya Undang-undang Nomor 22 Tahun 1999 tentang Otonomi Daerah dan Undang-undang Nomor 25 Tahun 1999 tentang Perimbangan Keuangan Pusat dan Daerah, merupakan perwujudan dari kebijakan pemerintah pusat untuk memberdayakan dan meningkatkan kemampuan masyarakat di daerah dalam rangka meningkatkan perekonomian daerah. Kedua undang-undang tersebut, memiliki makna yang sangat penting bagi daerah karena adanya pemberian urusan, sumber daya manusia dan pembiayaan, yang selama ini merupakan tanggung jawab pemerintah pusat.

Caska \& Riadi (2012) melakukan penelitian dengan judul pertumbuhan dan ketimpangan pembangunan ekonomi antar daerah di provinsi Riau dengan menggunakan analisis indeks Williamson untuk ketimpangan pembangunan yang hasilnya selama periode pengamatan 2002-2005, terjadi keatimpangan pembangunan yang tidak cukup signifikan. Dalam pertumbuhan ekonomi daerah provinsi Riau, daerah yang termasuk daerah yang mengalami cepat maju dan cepat tumbuh (hight growth and hight income) hanya 1 (satu) daerah saja yakni kota pekanbaru. Daerah atau kabupaten yang dikategorikan berkembang cepat dalam arti pertumbuhan (hight growth but low income) adalah kabupaten Pelalawan, Kuantan Singingi, Indragiri Hulu dan kabupaten Siak. Untuk daerah atau kabupaten yang maju tapi tertekan (hight income but low growth) adalah pada Kabupaten Indragiri Hilir, Rokan Hulu dan Kabupaten Kampar, 
sedangkan daerah yang pembangunan atau pertumbuhan ekonominya relatif tertinggal adalah Kabupaten Rokan Hilir, Dumai dan Kabupaten Bengkalis.

Maslili, melakukan penelitian dengan judul analisis factor-faktor yang mempengaruhi pertumbuhan ekonomi dan ketimpangan regional antar kabupaten/kota di provinsi Jawa Barat dengan menggunakan analisis indeks Williamson untuk mengetahui ketimpangan regional dengan hasiltingkat ketimpangan antar kabupaten/kota di Jawa barat pada priode penelitian antara tahun 1993-2006 cenderung meningkat. Menurut analisis tipologi klassen untuk mengetahui klasifikasi pertumbuhan ekonomi pada kabupaten/kota di Jawa barat pada periode penelitian antara tahun 19932006 termasuk klasifikasi daerah relative tertinggal. Restiatun (2009) melakukan penelitian dengan judul identifikasi sector unggulan dan ketimpangan antar kabupaten/kota di provinsi Daerah Istimewa Yogyakarta dengan menggunakan analisis indeks Williamson untuk mengetahui ketimpangan pembangunan antar kabupaten dengan hasil selama tahun 1993-2003 ketimpangan cenderung meningkat. Analisis tipologi klassen untuk mengetahui posisi perekonomian masing-masing kabupaten dengan hasil kota Yogyakarta masuk dalam klasifikasi daerah cepat maju dan cepat tumbuh, Sleman dan Gunung Kidul termasuk kedalam klasifikasi daerah berkembang cepat sedangkan yang termasuk kedalam daerah relative tertinggal adalah Bantul dan Kulon Progo.

Dari ketiga penelitian tersebut dapat disimpulkan bahwa dalam menghitung ketimpangan pembangunan menggunakan analisis Indeks Williamson dan untuk mengetahui klasifikasi pertumbuhan ekonomi daerah menggunakan analisis tipologi klassen.

\section{METODE PENELITIAN}

Penelitian ini menggunakan analisis data skunder. Penelitian ini dilakukan pada daerah Sumatera Utara bagian Timur, yaitu Kabupaten Batubara, Kabupaten Asahan, Kabupaten Tanjung Balai, Kabupaten Labuhan Batu Utara, Kabupaten Labuhan Batu Selatan. Data yang digunakan adalah data skunder yang diproleh dari pihak terkait. Data yang diperlukan yaitu Data Produk Domestik Regional Bruto per kapita menurut Kabupaten/Kota atas dasar harga konstan 2000 (rupiah) 2010-2012, laju pertumbuhan ekonomi 
menurut kabupaten/Kota atas dasar harga konstan 2000 (persen) 2010-2012, dan jumlah penduduk menurut Kabupaten/Kota tahun 2010-2012. Adapun analisis yang digunakan dalam penelitian ini, yaitu:

1. Analisis ketimpangan pembangunan daerah yaitu indeks Williamson yakni analisis yang digunakan sebagai indeks ketimpangan regional (regional inequality) dengan rumusan sebagi berikut:

$$
I W=\sqrt{\sum \frac{\left(Y_{i}-Y\right)^{2} f_{i} / n}{Y}}
$$

Dimana:

$Y_{i}=$ PDRB perkapita di kabupaten $\mathrm{i}$

$Y=$ PDRB perkapita rata-rata di provinsi sumatera utara

$f_{i}=$ Jumlah penduduk dikabupaten $\mathrm{i}$

$n=$ Jumlah penduduk di provinsi sumatera utara

Dengan indikator bahwa apabila angka indeks ketimpangan Williamson semakin mendekati nol, maka menunjukkan ketimpangan yang semakin kecil dan bila angka indeks menunjukkan semakin jauh dari hasil nol maka menunjukkan ketimpangan yang semakin melebar.

2. Analisis Tipologi Klassen yaitu analisis yang digunakan untuk mengetahui gambaran tentang pola pertumbuhan ekonomi masingmasing daerah serta menunjukkan pemetaan ketimpangan masingmasing daerah. Kriteria yang digunakan terdiri empat:

a) Kuadaran I (pertama) yakni daerah cepat maju dan cepat tumbuh (high income and high growth) adalah daerah yang memiliki pertumbuhan ekonomi dan pendapatan perkapita yang lebih tinggi dibandingkan dengan Provinsi Sumatera Utara

b) Kuadran II (kedua) yakni daerah maju tapi tertekan (high income but low growth) adalah daerah yang memiliki pendapatan per kapita lebih tinggi, tetapi tingkat pertumbuhannya lebih rendah dibandingkan dengan Provinsi Utara 
c) Kuadaran III (ketiga) yakni daerah berkembang cepat (high growth but low income) adalah daerah yang memiliki tingkat pertumbuhan tinggi, tetapi tingkat pendapatan perkapita lebih rendah dibandingkan dengan Provinsi Utara

d) Dan kuadaran IV (keempat) adalah daerah relatif tertinggal (low growth and low income) adalah daerah yang memiliki tingkat pertumbuhan ekonomi dan pendapatan per kapita lebih rendah dibandingkan dengan Provinsi Utara

Table 1. Klasifikasi Wilayah Menurut Tipologi Klassen.

PDRB Perkapita (y)/

Laju Pertumbuhan Ekonomi Yi $>\mathbf{y} \quad$ Yi $<\mathbf{y}$

(r)

\begin{tabular}{lll}
\hline \multirow{2}{*}{$\mathbf{i}>\mathbf{r}$} & KUADRAN I & KUADRAN III \\
& $\begin{array}{l}\text { Daerah cepat maju } \\
\text { dan Cepat Tumbuh }\end{array}$ & $\begin{array}{l}\text { Daerah } \\
\text { Berkembang Cepat }\end{array}$ \\
\hline \multirow{2}{*}{$\mathbf{R}<\mathbf{r}$} & KUADRAN II & KUADRAN IV \\
& $\begin{array}{l}\text { Daerah Maju tapi } \\
\text { tertekan }\end{array}$ & $\begin{array}{l}\text { Daerah tertinggal } \\
\text { telatif }\end{array}$ \\
\hline
\end{tabular}

Sumber: Maipita, PPT Ketimpangan Pembangunan Regional

Keterangan:

$\mathrm{Ri}=$ Laju Pertumbuhan PDRB wilayah i

$\mathrm{r}=$ Laju Pertumbuhan PDRB wilayah referensi

$\mathrm{Yi}=$ PDRB perkapita wilayah $\mathrm{i}$

$\mathrm{y}=$ PDRB perkapita wilayah referensi

\section{HASIL DAN PEMBAHASAN}

Ketimpangan Pembangunan Antar Kabupaten/Kota Sumatera Utara Bagian Timur

Analisis tingkat ketimpangan pembangunan dilakukan dengan melihat perkembangan PDRB, PDRB per kapita dan jumlah penduduk tiap-tiap kabupaten dengan mengabaikan faktor-faktor lain khususnya faktor non ekonomi yang dapat menghambat dan mendorong tingkat pembangunan suatu daerah. Tabel 2 dan Grafik 1 menunjukkan tingkat ketimpangan di Sumatera Utara bagian Timur periode 2010-2012. 
Berdasarkan Tabel 2 menunjukkan hasil analisis ketimpangan Index Williamson Provinsi Sumatera Utara Bagian Timur pada tahun 2010-2012 untuk Kabupaten Asahan, Batubara, Labuhan Batu, Labuhan Batu Utara, Labuhan Batu Selatan, dan Kota Tanjung balai, bahwa tingkat ketimpangan pembanngunan jauh dari 0, itu berarti secara keseluruhan kabupaten /Kota Provinsi Sumatera utara Bagian Timur memiliki Ketimpangan yang sangat tinggi. Namun, seperti ditunjukkan pada Grafik 1 ketimpangan pembangunan pada Kabupaten/Kota Provinsi Sumatera Utara bagian timur daerah yang ekstrim ketimpangannya pada tahun 2010 adalah Labuhan batu selatan yang mencapai 2,3 ,akan tetapi untuk tahun berikut nya Labuhan Batu Selatan sudah menunjukkan penurunan ketimpangan meskipun tingkat ketimpangan nya masih tergolong tinggi yaitu 1,36 dan 1,28. Kemudian pada Tahun 2011 yang menjadi daerah ekstrim ketimpangan adalah kabupaten Batubara yang mencapai 2,93. Akan tetapi pada tahun berikutnya Batubara mampu mencapai ketimpangan yang paling rendah dibandingkan daerah lainnya yaitu 1, dan untuk tahun 2012 yang menjadi daerah ekstrim adalah Kabupaten Labuhan Batu yaitu 1,96 padahal pada tahun sebelumnya hanya mencapai 1,2 bearti terjadinya kenaikan ketimpangan pembangunan.

Tabel 2. Indeks Williamson Sumatera Utara Bagian Timur Tahun 20102012

\begin{tabular}{llllll}
\hline No. & Kabupaten & IW 2010 & IW 2011 & IW 2012 & $\begin{array}{l}\text { Rata-Rata } \\
\text { IW }\end{array}$ \\
\hline 1 & Asahan & 1,8 & 1,2 & 1,96 & 1,66 \\
2 & BatuBara & 1,2 & 2,93 & 1 & 1,71 \\
3 & Labuhan Batu & 1,5 & 1,01 & 3,12 & 1,88 \\
4 & Labuhan Batu Selatan & 2,3 & 1,36 & 1,28 & 1,63 \\
5 & Labuhan Batu Utara & 1,6 & 1,08 & 1,41 & 1,36 \\
6 & Tanjung Balai & 1,6 & 1,21 & 1,14 & 1,33 \\
& & & & 1,65 & 1,66 \\
\hline
\end{tabular}

Sumber : Data Olahan

QE Journal | Vol.04 - No.04 December 2015 - 243 


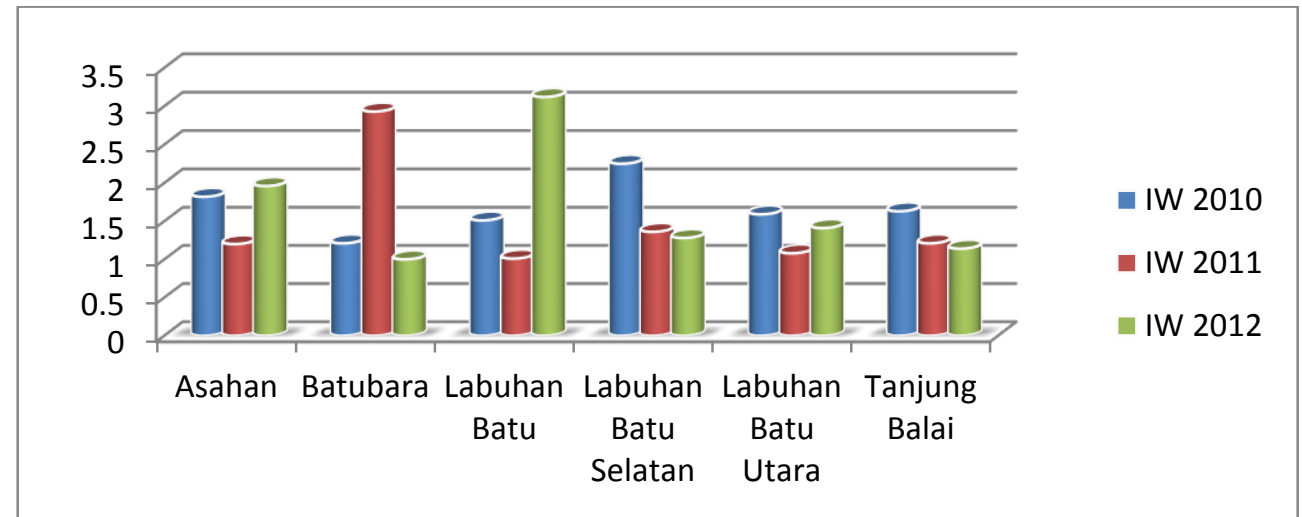

Sumber: Data olahan

Gambar 1.Grafik Indeks Williamson perdaerah Sumatera Utara bagian Timur 2010-2012.

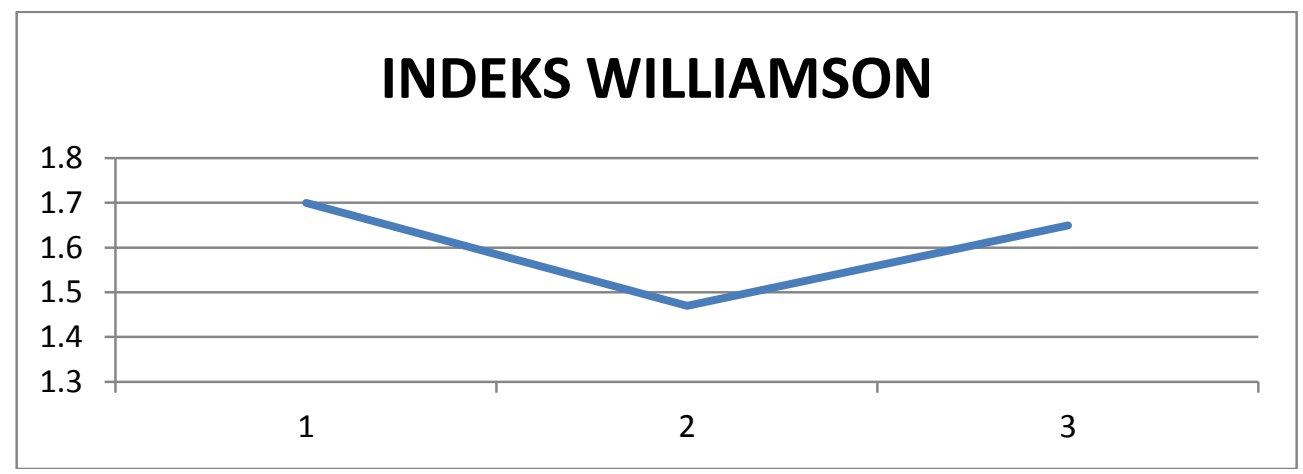

Sumber: Data Olahan

Gambar 2. Indeks Williamson Sumatera Utara bagian Timur Pada tahun 2010-2012

Tabel 2 diatas menunjukkan bahwa indeks ketimpangan pembangunan berdasarkan PDRB perkapita di Provinsi Sumatera Utara Bagian Timur selama periode 2010-2012 rata-rata sebesar 1,66. Selama tahun 2010-2011, terjadi penurunan ketimpangan dari 1,7 -1,47, hal ini berarti membuktikan bahwa secara keseluruhan pembangunan pada bagian timur sumatera utara ini sudah mengalami peningkatan. Namun pada tahun 2012 ketimpangan pembangunan untuk sumatera bagian timur kembali meningkat yaitu 1,66. Hal ini membuktikan bahwa ketimpangan pembangunan sangat tinggi karena ketidakmerataan pembangunan. 


\section{Klasifikasi pertumbuhan Tipology Klassen}

Untuk mengetahui klasifikasi daerah didasarkan kepada dua indikator utama yaitu pertumbuhan ekonomi dan pendapatan atau Produk Domestik Regional Bruto per kapita. Dengan menentukan rata-rata Produk Domestik Regional Bruto (PDRB) per kapita sebagai sumbu horizontal, dan laju pertumbuhan sebagai sumbu vertical. Sedangkan daerah per kabupaten dibagi menjadi empat klasifikasi yaitu kabupaten yang cepat maju dan cepat tumbuh (high growth and high income), kabupaten maju tapi tertekan (high income but low growth), kabupaten yang berkembang cepat (high growth but low income) dan kabupaten yang relatif tertinggal (low growth and low income.

Tabel 3. PDRB Per Kapita Provinsi Sumatera Sumatera Utara Bagian Timur (rupiah).

\begin{tabular}{llllll}
\hline \multirow{2}{*}{ NO. } & KABUPATEN & \multicolumn{2}{l}{ PDRB PERKAPITA } & RATA- \\
\cline { 3 - 5 } & & $\mathbf{2 0 1 0}$ & $\mathbf{2 0 1 1}^{*}$ & $\mathbf{2 0 1 2}^{* *}$ & RATA \\
\hline 1 & Asahan & 8065320 & 8420068 & 8844690 & 8443359.33 \\
\hline 2 & Batubara & 19672216 & 20485047 & 21288665 & 20481976 \\
\hline 3 & Labuhan batu & 7857113 & 8229694 & 8616226 & 8234344.33 \\
\hline 4 & Labuhan batu selatan & 10212617 & 10737944 & 11235828 & 10728796.3 \\
\hline 5 & Labuhan batu utara & 9565185 & 10065377 & 10654210 & 10094924 \\
\hline 6 & Tanjung balai & 9043279 & 9394860 & 9782507 & 9406882 \\
\hline & SUMUT & 10735955 & 11222165 & 11737021 & 11231713.7 \\
\hline
\end{tabular}

Sumber : Badan Pusat Statistic 2010-2012 (Data Olahan)

Data Sementara*

Data Sangat Sementara**

Tabel 4. Laju Pertumbuhan Ekonomi Menurut Kabupaten Kota

\begin{tabular}{llcccc}
\hline \multirow{2}{*}{ No } & Kabupaten & \multicolumn{2}{c}{ Tahun } & Rata- rata \\
\cline { 3 - 5 } & & $\mathbf{2 0 1 0}$ & $\mathbf{2 0 1 1}^{*}$ & $\mathbf{2 0 1 2}^{* *}$ & \\
\hline 1 & Asahan & 4.97 & 5.37 & 5.57 & 5.3 \\
\hline 2 & Batubara & 4.65 & 5.11 & 4.37 & 4.7 \\
\hline 3 & Labuhan batu & 5.61 & 6.13 & 6.33 & 6 \\
\hline 4 & Labuhan batu selatan & 5.68 & 6.21 & 6.38 & 6.1 \\
\hline 5 & Labuhan batu utara & 5.15 & 5.72 & 6.11 & 5.7 \\
\hline 6 & Tanjung balai & 4.76 & 4.86 & 4.9 & 4.8 \\
\hline
\end{tabular}




\begin{tabular}{lllll}
\hline SUMUT & 5.14 & 5.57 & 5.61 & 5.4 \\
\hline
\end{tabular}

Sumber: Badan Pusat Statistik, 2010-2012

Data Sementara *

Data Sangat Sementara **

Selama Tahun 2010-2012, rata-rata PDRB Per Kapita harga konstan tahun 2000 Provinsi Sumatera Utara sebesar 11231713.7. Tidak ada daerah yang rata-ratanya lebih tinggi dari pada rata-rata Provinsi Sumatera Utara Bagian Timur. Untuk pertumbuhan ekonomi menurut kabupaten/kota atas harga konstan tahun 2000, selama 3 (tiga) tahun yakni tahun 2010,2011 dan 2012 rata-rata tertinggi dimiliki oleh Labuhan batu dan Labuhan batu selatan yakni sebesar 5,66 dan 6,02. Sedangkan yang terendah dimiliki oleh Batubara dan Tanjung balai yakni masing-masing sebesar 4,71 dan 4.87.

Dari Tabel 3 dan Tabel 4, dapat diketahui bahwa daerah yang mengalami cepat maju dan cepat tumbuh ( high growth and high income) tidak ada. Daerah atau kabupaten yang dikategorikan berkembang cepat dalam arti pertumbuhan (high growth but low income) adalah kabupaten Labuhan Batu, Labuhan Batu Utara dan labuhan Batu selatan. Untuk daerah atau Kabupaten yang maju tapi tertekan ( high income but low growth) adalah pada kabupaten Batubara, sedangkan daerah yang pembangunan yang relative tertinggal adalah Kabupaten Tanjung balai dan Asahan.

Tabel. 5 Klasifikasi Pertumbuhan Ekonomi Sumatera Utara Bagian Timur berdasarkan Tipologi Klassen

\begin{tabular}{c|c}
\hline KUADRAN I & KUADRAN III \\
Daerah cepat maju dan Cepat Tumbuh & Daerah Berkembang Cepat \\
- & Labuhan Batu \\
& Labuhan Batu Selatan \\
Labuhan Batu utara
\end{tabular}

Sumber: Data Olahan

QE Journal | Vol.04 - No.04 December 2015 - 246 
Keterangan:

Kuadran I:Tidak ada Kabupaten/ Kota Provinsi Sumatera Utara bagian Timur yang mengalami laju pertumbuhan PDRB dan tingkat pendapatan per kapita yang lebih tinggi dari rata-rata seluruh daerah. Pada dasarnya daerah-daerah tersebut merupakan daerah yang paling maju, baik dari segi tingkat pembangunan maupun kecepatan pertumbuhan. Biasanya daerahdaerah ini merupakan merupakan daerah yang mempunyai potensi pembangunan yang sangat besar dan telah dimanfaatkan secara baik untuk kemakmuran masyarakat setempat. Karena diperkirakan daerah ini akan terus berkembang dimasa mendatang.

Kuadran II :Kabupaten Batubara adalah satu-satunya Kabupaten dari Provinsi Sumatera Utara bagian Timur yang -daerah yang relatif maju tetapi tertekan dalam beberapa tahun terakhir laju pertumbuhannya menurun akibat tertekannya kegiatan utama daerah yang bersangkutan. Karena itu, walaupun daerah ini merupakan daerah telah maju tetapi dimasa mendatang diperkirakan pertumbuhannya tidak akan begitu cepat, walaupun potensi pembangunan yang dimiliki pada dasarnya sangat besar.

Kuadran III:Ada tiga kabupaten yang termasuk kedalam daerah yang berkembang cepat, yaitu:1). Labuhan Batu, 2). Labuhan Batu Selatan 3). Labuhan Batu Selatan, daerah tersebut merupakan daerah yang memiliki potensi pengembangan sangat besar, tetapi masih belum diolah secara baik. Oleh karena itu, walaupun tingkat pertumbuhan ekonominya tinggi namun tingkat pendapatan per kapitanya, yang mencerminkan tahap pembangunan yang telah dicapai sebenarnya masih relatif rendah dibandingkan dengan daerah-daerah lain. Karena itu dimasa mendatang daerah ini diperkirakan mampu berkembang dengan pesat untuk mengejar ketertinggalannya dengan daerah maju.

Kuadran IV:Ada dua kabupaten yang termasuk kedalam daerah yang relative tertinggal, yaitu Kabupaten Asahan dan Kota Tanjung balai. Daerah tersebut merupakan daerah yang mempunyai tingkat pertumbuhan dan pendapatan per kapita yang berada dibawah rata-rata dari seluruh daerah. Ini berarti bahwa baik tingkat kemakmuran masyarakat maupun tingkat pertumbuhan ekonomi di daerah ini masih relatif rendah. Tetapi hal ini tidak berarti bahwa didaerah ini tidak akan berkembang di masa mendatang. Melalui pengembangan sarana dan prasarana perekonomian daerah berikut tingkat pendidikan dan 
pengetahuan masyarakat setempat diperkirakan daerah ini secara bertahap akan dapat pula mengejar ketertinggalannya.

\section{KESIMPULAN}

Berdasarkan hasil analisis dan pembahasan yang telah diuraikan pada sebelumnya, dapat disimpulkan bahwa:

1. Dengan menggunakan PDRB perkapita harga konstan tahun 2000, hasil analisis Indeks Williamson menyatakan tingkat ketimpangan antar kabupaten di Sumatera utara bagian timur pada tahun 2010-2012 sangat tinggi. Pada tahun 2010 mencapai 1,7 kemudaian untuk tahun 2011 mengalami penurunan mencapai 1,47 dan pada tahun 2012 mengalami peningkatan kembali mencapai 1,66. Untuk daerah ekstrim ketimpangan tiap tahun berbeda yaitu 2010-2011 masing-masing Labuhan Batu Selatan, Batubara dan Labuhan Batu.

2. Pertumbuhan ekonomi PDRB daerah Provinsi Sumatera Utara bagian timur, dapat diketahui bahwa daerah yang mengalami cepat maju dan cepat tumbuh ( high growth and high income) tidak ada. Daerah atau kabupaten yang dikategorikan berkembang cepat dalam arti pertumbuhan (high growth but low income) adalah kabupaten Labuhan Batu, Labuhan Batu Selatan, Labuhan Batu Utara . Untuk daerah atau Kabupaten yang maju tapi tertekan ( high income but low growth) adalah pada kabupaten Batubara, sedangkan daerah yang pembangunan yang relative tertinggal adalah Kabupaten Tanjung Balai dan Kabupaten Asahan

\section{DAFTAR PUSTAKA}

Alkarazkani, Fuktia.(2012).Ketimpangan pembangunan antar wilayah.dari: www.google.com/http://fuktiaAlkharazkani.blogspot.com/2012/0 4/ketimpangan-pembangunan-antar -wilayah.Html.

Badan Pusat Statistik (BPS).2013.Sumatera Utara Dalam Angka. 2013

Caska,RM.Rindi. Pertumbuhandan Ketimpangan Pembangunan Ekonomi. Jurnal Industri dan Perkotaan Volume XII Nomor 21, Februari 2008 (16291640). 
Chika, Chantika.(2014). Sebutkan Pengertian Pembangunan Menurut Para Ahli!: Menurut Schumpeter (dalam Suryana,2000:5).dari www.google.com/http://brainly.co.id/tugas/330525.

Ferdiman.(2013). Analisis Tipologi Klassen: Analisis Tipologi Klassen Kabupaten Aceh Utara Tahun 2008-2011.dari www.google.com/Fardiman.blogspot.com/2013/10/analisistipologi-klassen.html pada 30 Oktober 2013

Isnowati,Sri. Pengujian Hipotesis Kuznet diwilayah pembangunan I jawa Tengah. Jurnal Bisnis dan ekonomi. Vol.14. Maret 2007 (1-14).

Todaro,P.Michael\&Smith,C.Stephen.2011.Pembangunan Ekonomi. Erlangga, Jakarta. Perdana Publishing, Medan.

Restiatun. Identifikasi Sektor Unggulan dan Ketimpangan antar Kabupaten/Kota di Provinsi Daerah Istimewa Yogyakarta.Jurnal Ekonomi dan Studi Pembangunan Vol 10 Nomor 1, April 2009 (77-98)

Siahaan, Sarah Raya. Economic Growth Analysis and nequality between Mountainous Regions in North Sumatera, ISSN.0853-0203 18 (2), 2010 (262-270).

Zuswanto, Z.(2014). Faktor yang mempengaruhi pembangunan antar daerah menurut syafrizal:BAB-I Pdf. dari www.google.com/ http://eprints.ums.ac.id/29011/2/BAB-I.pdf. 